\title{
Gorontalo
}

Journal of Government and Political Studies

Volume 3 - NO. 2 - Oktober 2020

P-ISSN: 2614-2120 E-ISSN: 2614-2104

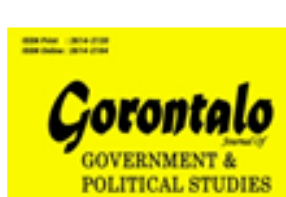

\section{Mengkaji Upaya Pemerintah Melalui Program Kartu Prakerja dalam Perspektif Pemberdayaan di Masa Pandemi Covid-19}

\author{
Tomi Predianto \\ Khoirurrosyidin \\ Universitas Muhammadiyah Ponorogo \\ Jl. Budi Utomo No. 10, Ronowijayan \\ Kabupaten Ponorogo, Jawa Timur, 63471 \\ prediantotomi22@gmail.com, rosyidin.kh@umpo.ac.id
}

Received: 19th September 2020; Revised: 24th September 2020;

Accepted: 25th September 2020

\begin{abstract}
The presence of the Kartu Prakerja program's in the midst of the COVID-19 pandemic seems to have indeed left several new kinds of problems which in essence ara related to the fate and needs of small society especially those affected by layoffs, economic difficulties, declining income, etc. In principle. The true of Kartu Prakerja is a bridge that is able to connect the society with a variety of new skills training. Beside of that, the government also expects the creation of a more capable and empowered society to simultaneously reduce excessive dependence on others. The access facilities to various training video tutorials, as well as the form of cash assistance provided by Kartu Prakerja program, actually quite spoil the society. But the problem is that not all small society can feel the opportunity, because the quota limitations per wave and the system is also implemented through the selection stage. Coupled with lawsuits from several public observers who essentially lamented the effectiveness of trillions of funds to be applied to the Kartu Prakerja program, because it's not efficient. This study seeks to assess the effectiveness of the Kartu Prakerja program in the perspective of empowerment, as well as impacts found in the field so far.
\end{abstract}

Keywords: empowerment; kartu prakerja; Covid-19

\begin{abstract}
ABSTRAK
Kehadiran program Kartu Prakerja di tengah masa Pandemi COVID-19 ini nampaknya memang menyisakan beberapa macam permasalahan baru yang pada esensi nya adalah berhubungan dengan nasib dan kebutuhan masyarakat kecil terutama yang terkena PHK, kesulitan ekonomi, penghasilan menurun, dsb. Secara prinsip, Kartu Prakerja sejatinya adalah menjadi jembatan yang mampu untuk menghubungkan masyarakat dengan berbagai macam pelatihan keterampilan baru. Selain itu, pemerintah juga mengharapkan terciptanya masyarakat yang lebih mampu dan berdaya untuk sekaligus mengurangi ketergantungan berlebih kepada orang lain. Fasilitas akses berbagai macam video tutorial pelatihan, serta bentuk bantuan dana tunai yang diberikan oleh program Kartu Prakerja, sebenarnya cukup memanjakan masyarakat. Namun permasalahannya adalah bahwa tidak semua masyarakat kecil dapat merasakan kesempatan tersebut, karena keterbatasan kuota per gelombangnya dan juga diterapkannya sistem melalui
\end{abstract}


tahapan seleksi. Ditambah lagi dengan gugatan dari beberapa pemerhati publik yang intinya menyayangkan efektivitas dana triliunan untuk diaplikasikan pada program Kartu Prakerja, karena tidak efisien. Penelitian ini berusaha mengkaji sejauh mana efektivitas Kartu Prakerja dalam perspektif pemberdayaan, serta dampak yang ditemukan di lapangan selama ini.

Kata Kunci: pemberdayaan; kartu prakerja; Covid-19

\section{PENDAHULUAN}

Pandemi COVID-19 merupakan satu wabah internasional yang saat ini tengah melanda hamper seluruh negara di penjuru dunia. COVID-19 menyebar secara luas dan cepat secara sifatnya, melalui perantara dari satu manusia ke manusia lain. Status covid saat ini memang menjadi begitu darurat, sebagai bukti adalah dengan melihat fakta di lapangan. Selain itu badan kesehatan dunia WHO juga telah memberikan pernyataan serius untuk mengingatkan penduduk dunia agar melakukan kebijakan yang tepat dalam mengantisipasi penyebaran COVID-19. Berbagai negara telah merasakan dampak yang begitu besar mulai dari ekonomi, pariwisata, hingga keadaan sosial masyarakat.

Sebagai contoh, dikutip dari Tirto.id (2020) bahwa beberapa negara memilih melakukan opsi lockdown seperti China, Italia, hingga Prancis. Bahkan negara China sendiri sudah sejak jauh-jauh hari menerapkan kebijakan lockdown, terutama di pusat wilayah penyebaran COVID-19 yakni di kota Wuhan. Setelah kasus meningkat, lebih dari itu negara China juga melakukan pembatasan massal dengan cara menutup akses untuk keluar masuk ke negara lain bagi para penduduknya, serta melarang beroperasinya transportasi publik secara total. Setelah itu, kebijakan lockdown menjadi percontohan bagi negara-negara lain yang pada akhirnya juga menerapkan dengan ketat (Gusman, 2020).

Cara yang dilakukan oleh negara-negara di dunia dalam mengatasi penyebaran COVID-19 bisa dibilang hampir sama antara satu dengan yang lain, seperti kebijakan lockdown serta pembatasan interaksi berskala besar guna meminimalisir bertambahnya korban. Jika ditelaah, pembatasan yang diakibatkan oleh lockdown tentunya turut mengganggu aktivitas normal di berbagai negara baik dari segi sosial, ekonomi, maupun pariwisata. Karena hampir tidak ada akses keluar masuk antar warga negara lain, secara otomatis hal ini melemahkan interaksi dan penambahan devisa. Dapat dikatakan bahwa hal ini adalah gejala yang normal, sebagai imbas dari adanya wabah internasional.

Salah satu negara yang terdampak akan kerugian dan tekanan akibat COVID-19 adalah Indonesia, yang mana mengalami himpitan ekonomi secara luas. Lesu nya keadaan ekonomi ini ditujukan untuk memutus mata rantai penyebaran COVID-19, dikarenakan berbagai pembatasan-pembatasan operasional yang melibatkan banyak perusahan besar serta para pelaku ekonomi lainnya. Pemberlakuan social distancing menjadi salah satu pemicu serta ditambah dengan Peraturan Pemerintah No.21 Tahun 2020 Tentang PSBB sebagai upaya untuk mempercepat pemulihan kondisi dan situasi. Kebijakan yang telah dilakukan oleh pemerintah Indonesia merupakan satu wujud penanganan serius. Tidak dapat dipungkiri aspek fundamental di negara Indonesia menjadi objek kritis yang menjadi fokus utama pemerintah (Consuello, 2020). 
Kerugian ekonomi nasional akibat adanya PSBB dapat diukur dari aktivitas dan mobilitas orang -orang yang ada di jabodetabek, sebagai daerah inti dan penyangga perekonomian. Sejak awal hingga pertengahan bulan Maret, terdapat penurunan secara drastis pada sektor dan sarana transportasi mulai dari pesawat terbang, kereta api komuter, bus, angkot, taksi, hingga skala ojek konvensional dan ojek online sekali pun. Sebagai data tambahan, yakni dikutip dari republika.co.id menyatakan bahwa PT.KAI ketika itu membatalkan perjalanan 44 rute dari Jakarta ke kota-kota lain. Demikian juga dengan maskapai penerbangan yang tidak beroperasi, serta keluhan dari para driver taksi, ojek konvensional, maupun ojek online yang mengaku bahwa terjadi penurunan jumlah penumpang sekitar 70 hingga $80 \%$ dari hari-hari biasanya, sehingga memaksa mereka untuk mandeg dan memilih untuk pulang ke kampung halaman masing-masing. Dengan adanya PSBB maka perkantoran dan sebagian besar industri dilarang beroperasi, untuk kurun yang relatif lama, dan menimbulkan kerugian ekonomi. Sedangkan apabila PSBB diperpanjang dan atau diperluas ke kota-kota lain, maka otomatis dampak kerugian membesar, dan dapat diproyeksikan berdasar perbandingan waktu dan luasan area (Hadiwardoyo, 2020).

Di masa COVID-19, salah satu kebijakan dan program yang diterapkan oleh pemerintah Indonesia adalah meluncurkan program Kartu Prakerja dengan melibatkan kemitraan dari multi-perusahaan. Program Kartu Prakerja menjadi begitu berarti untuk membantu masyarakat kecil dalam memenuhi kebutuhan hidup dan mempertahankan kesejahteraan pangan dalam jangka waktu tertentu. Dampak dari COVID-19 dapat dikatakan sedikit teratasi melalui program Kartu Prakerja, walaupun demikian tidak semua masyarakat mampu untuk mendapatkan akses program Kartu Prakerja dikarenakan banyak faktor yang berlaku seperti ketatnya proses seleksi, keterbatasan informasi, kemauan, minat, dan lain sebagainya. Kartu Prakerja muncul sebagai satu program yang memberikan ruang keterbukaan serta potensi untuk memicu perkembangan kreativitas bagi masyarakat kecil melalui sistem pelatihan secara online.

Di dalam program Kartu Prakerja, masyarakat juga disuguhkan dengan akses luas untuk meningkatkan kompetensi diri dalam bidang tertentu. Selain itu, berbagai platform digital juga menyertai proses dan pelayanan Prakerja seperti Tokopedia, Bukalapak, Skill Academy, Kemnaker, Pintaria, Pijar, Sekolah.mu, dan MauBelajarApa (Wijayanti \& Humardhiana, 2020).

Program Kartu Prakerja sangat relevan dengan teori dari Olaniyi (2020) yang menyatakan bahwa ketika keadaan ekonomi masyarakat menurun secara drastis, maka pemerintah pihak yang paling bertanggungjawab secara penuh untuk mengambil langkah strategis guna mengatasi kesulitan ekonomi yang menjangkit masyarakat. Keadaan ekonomi masyarakat merupakan acuan utama yang menjadi beban dan tanggungjawab pemerintah sebagai pihak berwenang, apalagi ketika keadaan darurat atau terjadi hambatan sewaktu-waktu (Kurniawansyah, et al 2020).

Akibat meluasnya pertambahan korban COVID-19, pemerintah Indonesia harus memutar otak untuk menyiasati problematika yang terjadi. Hal ini merupakan imbas dari menurunnya iklim usaha yang terjadi pada masyarakat indonesia mulai dari menurunnya tingkat produktivitas serta penutupan usaha dan PHK. Dalam hal ini pemerintah Indonesia adalah subjek yang bertanggungjawab terhadap ancaman perekonomian nasional. Melalui 
dikeluarkannya Perppu No.01 Tahun 2020, salah satu program yang digalakkan adalah Kartu Prakerja dengan target 5,6 juta masyarakat (khusus) yang terkena imbas dari pandemi COVID-19. Dalam program Kartu Prakerja, masyarakat memiliki hak ada dua hal yakni 900 jenis pelatihan online sebagai akses untuk meningkatkan kapabilitas diri (sesuai dengan bakat dan minat masing-masing), serta bantuan dana untuk keperluan lain (Pratiwi, 2020).

Secara mekanisme pendaftaran, pemerintah Indonesia tidak membedabedakan tiap-tiap individu. Semua memiliki kesempatan yang sama, asal WNI, telah berusia 18 tahun dan tidak sedang, dipersilahkan untuk melakukan pendaftaran secara online. Selanjutnya apabila para pendaftar telah dinyatakan lolos dalam seleksi berkas, maka tahap berikutnya adalah dilanjutkan dengan mengikuti tes motivasi dan kemampuan dasar. Bagi para peserta yang lolos, maka diperkenankan untuk mengikuti pelatihan dan akan mendapatkan sertifikat elektronik ketika pelatihan telah usai. Selain itu, sifat pencairan daripada uang pembinaan adalah dengan catatan bahwa peserta harus mengikuti bentuk pelatihan terlebih dahulu yang harapannya adalah digunakan untuk pengembangan serta modal diri secara lebih lanjut pasca pelatihan (Pratiwi, 2020).

Tindakan pemerintah merupakan sesuatu yang maklum perihal langkahlangkahnya dalam menetapkan kebijakan. Namun apabila kebijakan tersebut dikaitkan dengan relevansi terhadap situasi dan kondisi pada suatu Negara termasuk Indonesia, maka publik atau masyarakat akan terkena dampaknya secara langsung. Sehingga wujud dari kualitas kebijakan yang diterapkan oleh pemerintah, tentunya menjadi faktor penentu keadaan. Sebagai contoh adalah dalam hal Kartu Prakerja, dimana pemerintah memasukkan sentuhan dan perantara digital untuk memberdayakan masyarakat melalui berbagai macam pelatihan strategis. Dalam hal ini, dapat dilihat bagaimana upaya pemerintah untuk membekali warga masyarakat supaya menjadi terampil dan cekatan, untuk selanjutnya mampu menunjang kemampuan sehari-hari dalam bertahan hidup.

Kehadiran program Kartu Prakerja merupakan langkah strategis dari pemerintah Indonesia yang tentunya dilatarbelakangi atas dasar kepedulian tinggi terhadap warga masyarakat. Apalagi di masa pandemi COVID-19 seperti sekarang ini, dimana mayoritas masyarakat memang mengalami kebuntuan terutama soal pemenuhan kebutuhan (ekonomi). Segala aktivitas pun menjadi terhambat, atau memang menurun secara produktivitas dan penghasilan. Hal ini didukung dengan data penerimaan pajak yang mengalami tekanan akibat dari melemahnya tren industri serta aktivitas perdagangan dan ekonomi internasional. Di akhir bulan Maret 2020 baik sektor pemerintah dan usaha mengalami perlambatan usaha seiring dengan adanya aturan terkait WFH (Work From Home). Jika ditotal, Indonesia mengalami penurunan penerimaan pajak pada kuartal I-2020 yang tercatat mengalami minus sekitar 2,5\%, dan secara otomatis mempengaruhi angka APBN 2020. Adapun beberapa instrumen pajak yang minus setelah digunakan untuk penanganan Covid-19 adalah PPh Badan dan Pajak dalam rangka Impor (PDRI) terdiri beberapa jenis, yaitu Pajak Penghasilan (PPh) pasal 22 impor, PPh pasal 22 ekspor, Pajak Pertambahan Nilai (PPN) impor, dan Pajak Penjualan Barang Mewah (Silalahi \& Ginting, 2020).

Sehingga pada akhirnya berbagai alasan tersebut turut mendasari pemerintah dalam merumuskan ide, dan menjadikan pemerintah Indonesia 
bersikap aktif untuk membaca geliat kelesuan yang ada pada masyarakat kecil. Bagaimanapun, realisasi program kartu Prakerja hingga saat ini memang sudah terealisasi di lapangan. Kemudian, salah satu sasaran yang diharapkan oleh berlakunya program Kartu Prakerja adalah diantaranya seperti: masyarakat terdampak COVID-19, pelaku UMKM, dan masyarakat terdampak PHK.

Menurut data dari Kementrian Sosial beberapa dampak yang dirasakan oleh masyarakat memang tidak sedikit, yakni dalam bidang ekonomi, sosial, pendidikan, maupun kesehatan. Namun dampak yang paling besar memang terlihat dari bagaimana terbatasnya berbagai aktivitas masyarakat di luar rumah, karena mengindahkan himbauan pemerintah (PSBB) agar sebisa mungkin menahan diri untuk tidak keluar rumah kecuali memang memiliki urusan yang benar-benar genting. Pada akhirnya hal ini turut berimbas pada kondisi sosial ekonomi dari banyak masyarakat kecil dengan berbagai latarbelakang mata pencaharian, karena konteks nya adalah mereka harus tetap mempertahankan kelangsungan hidup untuk sementara waktu di tengah kondisi yang tidak memihak (Pratama, 2020).

Beberapa data tentang permasalahan sosial, ekonomi, pendidikan, dan kesehatan sebenarnya telah banyak bermunculan di berbagai fakta pemberitaan. Seperti beberapa contoh berikut. Yakni:

a. Permasalahan Ekonomi, dikutip dari (Anjaeni, 2020) bahwa Menteri Keuangan Sri Mulyani mengungkapkan setidaknya terdapat 3 kasus ekonomi di dalam negeri, seperti:

1) Pada sektor UMKM dan informal karena pembatasan interaksi dan kontak fisik, sehingga aktivitas ekonomi menurun.

2) Investasi yang melemah akibat adanya ketidakpastian, baik bagi pihak yang akan melakukan invetasi, maupun pihak yang sedang menjalankan investasi.

3) Sektor ekspor yang terpukul, karena seluruh dunia mengalami pelemahan. Hal tersebut tercemin dari penurunan harga komoditas dari minyak, batubara, hingga Crude Palm Oil (CPO).

b. Permasalahan Sosial, dikutip dari (Puspensos, 2020) dijelaskan bahwa terjadi disfungsi sosial di lapisan masyarakat akibat COVID-19. Contoh dari gejala disfungsi sosial adalah sikap dari masyarakat yang menjadi lebih rentan terhadap rasa curiga, karena menganggap orang lain tersebut membawa COVID-19 di dalam tubuhnya. Seperti masyarakat yang ada di Sawangan Depok, yang menolak penguburan jenazah meninggal Akibat COVID-19. Mereka menganggap bahwa COVID-19 akan terus menyebar, sekali pun jenazah telah dikuburkan. Padahal secara medis, jenazah yang sudah diproses di Rumah Sakit tentunya tidak akan menimbulkan penyebaran virus kembali.

c. Permasalahan Pendidikan, dikutip dari (Sumardiyani, 2020) Walikota Bogor (Bima Arya) mengatakan kepada Menteri Pendidikan dan Kebudayaan (Nadiem Makarim) pada Juli 2020 bahwa akses kuota dan internet, permasalahan kurikulum belajar online, serta skema pembayaran biaya pendidikan menjadi momok utama.

Selain itu, terkait dengan kepedulian sosial dari pemerintah Indonesia sejatinya memang sudah dapat diukur dari realisasi program Kartu Prakerja. Bahkan bisa dibilang, dengan adanya program tersebut masyarakat berpotensi 
untuk meningkatkan kualitas diri dan sifat ketergantungan yang berlebihan terhadap orang lain. Maka dari itu, berdasarkan penjelasan di atas tentunya akan sangat menarik jika mengkaji tentang bagaimana wujud kepedulian pemerintah terhadap masyarakat menyikapi masa pandemi COVID-19 sampai hari ini. Karena di sisi lain, baik pemberdayaan maupun kesejahteraan merupakan agenda fundamental yang memang sudah seharusnya menjadi tanggung jawab dari pemerintah di Indonesia. Akan tetapi, dalam penelitian ini yang menjadi fokus utama adalah tentang bagaimana pemerintah memunculkan ide dan solusi yang juga didukung oleh banyak platform digital sehingga memunculkan terobosan baru berupa program Kartu Prakerja. Tingkat efektivitas program kartu Prakerja pada akhirnya juga memiliki relevansi dengan wacana pemberdayaan masyarakat, dan selebihnya tergantung dari cara pemerintah untuk melakukan pengelolaan progam tersebut. Selain itu terkait dengan akses yang terlalu bebas bagi masyarakat tanpa disertai dengan perhatian terhadap latarbelakang ekonomi, juga turut memunculkan permasalahan baru.

Walaupun sejatinya secara prinsip pemerintah telah berkomitmen untuk meluncurkan program Kartu Prakerja untuk masyarakat terdampak pandemi COVID-19, namun tetap saja pemerintah tidak mampu untuk mengontrol secara penuh antusiasme masyarakat yang mendaftar. Bukankah sangat dimungkinkan jika sebagian dari para pendaftar adalah berada dalam keadaan yang lumayan baik, atau pun dalam arti lain adalah berkecukupan. Jika ditelaah, hal tersebut adalah suatu ketimpangan dimana kelompok masyarakat yang benar-benar membutuhkan akan secara otomatis tersingkir (akibat proses seleksi). Jika dibandingkan antara prinsip pemerintah dan praktik penyerapan peserta Kartu Prakerja di lapangan, korelasi nya sangat rancu memang, namun pada akhirnya kemungkinan tersebut dapat memunculkan satu hipotesis baru yang perlu mendapat perhatian khusus.

\section{METODE PENELITIAN}

Metode yang digunakan dalam penelitian ini merupakan studi kepustakaan (library research) dengan cara mengambil rujukan maupun bahan acuan dari berbagai sumber tulisan ilmiah seperti jurnal, buletin, pemberitaan media, maupun website resmi milik pemerintah yang tentunya relevan dengan topik yang dibahas. Studi kepustakaan memiliki arti sebagai suatu aktivitas dalam kegiatan pengumpulan sumber-sumber data pustaka, serta melakukan pengolahan terhadap data penelitian tersebut (Zed dalam Supriyadi, 2017).

Penelitian ini mengkaji tentang bagaimana upaya Pemerintah selama ini dalam melakukan upaya pemberdayaan kepada masyarakat, melalui dicanangkan nya program baru bernama Kartu Prakerja. Terlebih lagi di masa pandemi COVID-19 yang memang mengharuskan pemerintah untuk mencari terobosan maupun siasat baru, dikarenakan krisis terjadi dimana-mana dan pada berbagai sektor. Sehingga masyarakat merasa terhimpit dari segi keadaan, kemampuan, keterampilan, maupun daya untuk bertahan hidup. 


\section{HASIL DAN PEMBAHASAN}

\section{a. Menakar Efektivitas Program Kartu Prakerja}

Program Kartu Prakerja merupakan wujud realisasi dari pasal 27 Ayat (2) UUD tahun 1945 yang berbunyi: "Tiap-tiap warga negara berhak atas pekerjaan dan penghidupan yang layak bagi kemanusiaan". Jika dicermati, ada dua frasa inti di pasal tersebut, yakni; berhak atas pekerjaan dan penghidupan yang layak. Bentuk Kartu Pra-kerja ini sendiri hanya sebatas untuk memberikan penghidupan yang layak. Lalu untuk pekerjaannya? Disini pemerintah pun tidak memberi jaminan apakah setelah mengikuti rangkaian kegiatan yang terdapat dalam program Kartu Pra-Kerja, akan mendapat pekerjaan atau tidak (Consuello, 2020).

Sejumlah masyarakat juga menyampaikan keluhan dalam menyikapi realisasi program kartu Prakerja selama ini, karena berulang kali mendaftar hasilnya pun tetap nihil (tidak lolos) seleksi bahkan hingga gelombang ke-7. Walaupun pihak manajemen prakerja memberikan akses untuk pengaduan, apabila ada peserta yang tidak kunjung lolos dalam kurun waktu 3 kali berturut-turut dengan cara mengunduh lampiran surat pernyataan, kemudian mengisi nya dan mengirimkan kembali. Dikatakan bahwa masih disediakan kuota sebesar 1,8 juta penerimaan, maka dari itu pihak manajemen prakerja berupaya memberikan kesempatan dan dukungan kepada para pendaftar (Cone, 2020).

Jika dilihat secara fakta, maka program Kartu Prakerja merupakan bentuk kebijakan yang memang telah terealisasi secara penerapan program. Entah apa pun alasannya, yang jelas keberanian pemerintah dalam melakukan launching terhadap program Kartu Prakerja adalah sebagai suatu wujud ide dan gagasan nyata. Apabila kita berfikir panjang dan serius terhadap program ini, tentu saja kita boleh berfikir bahwa pemerintah memang telah melakukan perencanaan dan diskusi matang tentang simulasi program Kartu Prakerja sebelum diaplikasikan dengan resmi.

Selain itu, sangat dimungkinkan jika pemerintah juga memiliki banyak pertimbangan-pertimbangan strategis yang ditinjau dari berbagai segi. Pertimbangan yang rasional adalah lebih kepada upaya untuk memberdayakan masyarakat melalui pelatihan secara online, kemudian output yang diharapkan adalah agar kualitas SDM (Sumber Daya Manusia) menjadi meningkat, lalu pada akhirnya mampu untuk menjadi modal jangka panjang bagi kehidupan masyarakat.

Menurut data dari Badan Pusat Statistik (BPS), jumlah tingkat pengangguran terbuka per-Februari 2018 sebesar 5,13\%, angka yang masih terbilang besar untuk salah satu indeks yang menjadi tolok ukur sebuah negara yang telah berada dalam kesejahteraan atau justru malah masih terjerembab dalam kemiskinan. Berdasarkan data BPS, per Agustus 2019, jumlah pengangguran lulusan universitas mencapai 5,67 persen dan TPT untuk Sekolah Menengah Kejuruan (SMK) tertinggi diantara tingkat pendidikan lain yaitu sebesar 8,92 persen dari total angkatan kerja sekitar 13 juta orang. Belum lagi ditambah dengan seluruh pekerja atau buruh yang terkena PHK akibat dampak dari Covid-19 (Consuello, 2020).

Masyarakat adalah subjek yang paling dasar untuk diperhatikan oleh pemerintah secara sosial-ekonomi, karena jumlahnya yang banyak serta di sisi lain merupakan beban moral bagi pemerintah itu sendiri. Apalagi di masa 
pandemi COVID-19 seperti sekarang ini, tuntutan kebutuhan dari masyarakat adalah hal mutlak yang tidak dapat ditolak kedatangannya. Dalam hal pemenuhan kebutuhan pangan saja misalnya, dimana selama ini sudah menjadi agenda besar dari banyak negara termasuk Indonesia sendiri. Pemerintah Indonesia dapat disebut pula sebagai support system bagi keberlangsungan hidup masyarakat, terutama dari aspek sosialnya dan ekonomi nya.

Program Kartu Prakerja membuktikan bahwa posisi pemerintah adalah menyokong dan mendorong masyarakat untuk mampu meningkatkan level diri, dimana hal ini sejalan dengan konsep dari Usman (1995) dalam (Andreas, 2016) yang menjelaskan bahwa pemberdayaan (employment) diartikan sebagai "upaya untuk memaksimalkan potensi diri yang sebelumnya sudah dimiliki oleh masyarakat". Secara tidak langsung, makna dari pemberdayaan sendiri merupakan satu istilah yang mengandung unsur "partisipasi" dari internal masyarakat. Selain itu, efektivitas dari program Kartu Prakerja juga dapat diukur dari beberapa aspek milik Girvan (2006) dalam (Andreas, 2016) yakni seperti pada orientasi maupun tujuan yang hendak dicapai oleh sebuah perubahan sosial dimana pertimbangannya adalah: 1) masyarakat miskin atau lemah yang menjadi berdaya; 2) memiliki pengetahuan dan kemampuan dalam memenuhi kebutuhan hidup yang bersifat fisik, ekonomi, maupun social; 3) mampu menyampaikan aspirasi; 4) mempunyai atau membangkitkan mata pencaharian; 5) berpartisipasi dalam kegiatan kelompok (pelatihan, kursus, pertemuan, dsb) dan 6) mandiri dalam menjalankan kehidupannya masingmasing.

Dari beberapa poin dan pendapat para ahli di atas, bisa dibilang bahwa unsur-unsur yang ada di dalam program Kartu Prakerja memang memiliki relevansi kuat. Pengembangan potensi yang ada di masyarakat merupakan salah satu aspek yang oleh pemerintah berusaha untuk diserap, lalu diarahkan sesuai dengan koridor masing-masing. Upaya pemerintah dalam meluncurkan program Kartu Prakerja di Indonesia, adalah bagian dari prospek jangka panjang yang lambat laun akan nampak kelihatan hasilnya seperti apa. Jika berbicara mengenai harapan, maka setiap orang pasti berlomba-lomba untuk mencari ruang terbaik sekaligus ajang untuk mengaktualisasikan dirinya. Kartu Prakerja memberikan akses seluas-luasnya bagi para peserta untuk menekuni hal-hal baru, serta merubah kondisi dari tidak tahu menjadi tahu, dari tidak terampil menjadi lebih terampil. Lebih dari itu, efektivitas dari sistem dan konsep Kartu Prakerja juga turut memunculkan harapan baru tentang semakin gandrung nya masyarakat dalam lingkungan positif melalui pelatihan/pembekalan, sehingga secara tidak langsung masyarakat juga terlatih untuk swadaya.

\section{b. Kartu Pra Kerja Dalam Koridor Kontra}

Kendati demikian, efektivitas dari Kartu Prakerja tidak dapat dinilai hanya dari tujuan dan realisasi nya yang telah berjalan selama ini. Karena kita tidak dapat menyangkal bahwa perbedaan kondisi, pandangan, maupun cara dari setiap orang untuk memaknai tentunya berbeda. Hal yang semestinya dipastikan adalah, tidak ada unsur keterpaksaan yang datang dari benak masyarakat dalam menanggapi bagaimana sejauh ini manfaat program Kartu Prakerja bagi dirinya, keluarganya, teman, maupun orang lain. Ranah masyarakat adalah ranah yang sangat fleksibel untuk dijadikan sebagai tolok 
ukur, baik itu oleh pemerintah maupun pihak lain. Persoalan mengenai kontra terhadap realisasi program Kartu Prakerja, sepertinya memang memerlukan peninjauan ulang dikarenakan muncul beragam gugatan dari publik.

Gugatan yang dimaksud adalah lebih kepada persepsi terhadap potensi penyelewengan dan ladang proyek bagi pihak-pihak (oknum tertentu). Apabila mengacu pada bentuk kemitraan yang telah dijalin oleh pemerintah dengan beberapa perusahaan penyedia layanan pelatihan online, maka ruang untuk berdebat tentu terbuka lebar mengingat anggaran untuk pengelolaan program Kartu Prakerja juga tidak sedikit hingga menyentuh angka triliun. Sebagaimana dikutip dari (CNN, 2020) dalam bentuk infografis yang berisi komentar-komentar dari para pemerhati kebijakan, yang intinya menganggap program Kartu Prakerja memang tidak efektif, serta rawan penyelewengan. Berikut adalah beberapa kutipan wawancara tersebut:

1) Fadli Zon menyatakan bahwa: "andaikata pemerintah tetap bersikukuh untuk membuat suatu pelatihan karena menganggap pelatihan tersebut sangat penting, maka patut dipertanyakan apakah masuk akal jika biaya pelatihan daring (online) berpotensi menghabiskan anggaran sekitar 5,6 Triliun rupiah. Selain itu, anggaran tersebut hanya akan habis hanya untuk membeli video-video tutorial".

2) Agus H. Yudhoyono menyatakan bahwa: "Kita perlu mencermati kembali relevansi kartu Prakerja sebesar 5,6 T. Kami mendorong dana tersebut dialokasikan untuk bantuan langsung pada buruh dan pekerja yang terdampak"

3) Ahmad Ali: "Perlu peninjauan kembali atas pelatihan daring yang melibatkan 8 penyedia layanan (provider). Selain itu telah juga mendapat gugatan dari publik, pelatihan tersebut juga rawan akan penyelewengan"

Menanggapi berbagai pendapat beberapa tokoh publik di atas, dapat disimpulkan bahwa sejatinya program Kartu Prakerja merupakan satu ide dan gagasan yang perlu mendapat perhatian dari banyak pihak dalam proses realisasinya di lapangan. Hal yang mungkin dapat dijadikan alasan utama adalah, mengingat program Kartu Prakerja adalah program perdana dari pemerintahan di era kepemimpinan Jokowi. Dimana program tersebut lebih berorientasi kepada gaya baru pelatihan secara online, sebagai cara untuk meningkatkan keterampilan bagi warga masyarakat yanf mendaftar.

Garis besar dari beberapa komentar yang dicuatkan adalah lebih kepada menuntut pemerintah untuk meninjau ulang perihal program Pra Kerja yang telah dijalankan. Selain itu para pemerhati juga menyertakan alasan-alasan logis yang sekaligus menjadi celah kekurangan bagi pihak pemerintah. Jika pemerintah ingin menerapkan prinsip good government, maka mau tidak mau segala aspirasi dan perkembangan opini yang mengalir pada ranah pubik harus lah diperhatikan dengan betul. Sebagai upaya yang dikeluarkan atas respon terhadap meluasnya penyebaran COVID-19 pada berbagai daerah di Indonesia, memang sudah semestinya masing-masing pihak terutama pemerintah tak boleh berdiam diri.

Demi menjunjung tinggi kemaslahatan orang banyak, pintu kerja sama yang seluas-luasnya harus terbuka lebar untuk memantapkan langkah guna menghadapi krisis pada berbagai sektor. Kerjasama yang dimaksud adalah juga dengan cara memperhatikan secara serius tentang bagaimana polemik yang terjadi di lapangan, atau pun dalam mengantisipasi berbagai kemungkinan 
terjadi di luar ekspektasi pemerintah selama ini. Jalur digital yang telah diterapkan oleh pemerintah, memang layak jika terus mendapati sorotan publik. Selain itu publik juga memiliki akses yang mudah untuk terus mengontrol perkembangan Kartu Prakerja.

\section{c. Penerapan Sistem Tak Sebanding dengan Kebutuhan (Antusiasme)}

Sesuai dengan definisi resmi nya, Kartu Prakerja adalah program yang fokus untuk pengembangan kompetensi pada masyarakat berupa bantuan biaya yang ditujukan untuk para pencari kerja, pekerja yang terkena $\mathrm{PKH}$, atau memang masyarakat yang membutuhkan tambahan kompetensi diri. Fakta nya program Kartu Prakerja adalah insiatif dan kolaboratif dari pihak pemerintah dan Swasta yang dimanajemen sedemikian supaya dengan tujuan untuk meningkatkan nilai bagi masyarakat maupun promotor untuk pihak swasta (Wijayanti \& Humardhiana, 2020).

Tidak dapat dipungkiri bahwa sebenarnya pemerintah telah mengatur beberapa kategori masyarakat yang tidak boleh ikut berpartisipasi untuk mendaftar program Kartu Prakerja. Sebagaimana dikutip dari website resmi (Prakerja, 2020), beberapa kategorinya adalah: 1) Pejabat Negara; 2) Pimpinan dan Anggota DPRD; 3) Aparatur Sipil Negara; 4) TNI; 5) Polri; 6) Kepala dan Perangkat Desa; dam 6) Direksi, Komisaris, dan Dewan Pengawas pada BUMN atau BUMD.

Berdasarkan fakta di lapangan, rencana yang telah direaliasikan oleh pemerintah melalui Program Pra Kerja memang tidak berjalan mulus dan tidak lepas dari segala kekurangan. Ditambah lagi dengan kemunculan pandemi COVID-19 yang turut menyita waktu, tenaga, maupun ide pemerintah untuk kembali menggagas ulang perencanaan yang sebelumnya pernah dilakukan. Bagaimana pun, segala kebijakan berhubungan dengan pengeluaran anggaran memang riskan dan perlu upaya maksimal baik setelah suatu program diterapkan maupun sebelum diterapkan.

Sementara itu, penerapan sistem atau pun metode dari Prakerja sendiri memang tidak bisa ditelan mentah-mentah. Jika memang pemerintah Indonesia mengacu pada keadilan sosial ekonomi bagi rakyat kecil yang berkebutuhan, maka prosedural penyaringan peserta seharusnya tidak dilakukan. Karena hal tersebut tidak benar-benar memberi keberpihakan yang luas kepada masyarakat kecil, terutama bagi masyarakat yang gagap teknologi dan terdampak COVID-19. Simulasi nya adalah ketika ada sebagian rakyat yang kesulitan untuk mengakses website dikarenakan tidak memiliki modal alat serta informasi, maka bukan tidak mungkin jika hal tersebut justru menghambat tujuan pemberdayaan yang selama ini digadang-gadang oleh pemerintah. Singkatnya adalah ketika setiap orang memiliki bebas akses entah itu kaya atau miskin, maka kurva kesenjangan menjadi semakin tak terlihat. Secara tidak langsung sistem penjaringan peserta dalam program Kartu Prakerja adalah menyamakan status sosial ekonomi antara orang yang satu dengan orang lainnya, tanpa mengedepankan prioritas kebutuhan yang sebenarnya adalah aspek paling fundamental.

Beberapa warning pada posisi pekerjaan dalam program Kartu Prakerja tentunya sudah menjadi sesuatu yang maklum, namun jika dianalisa lebih dalam maka sebenarnya pemerintah kurang maksimal dalam mengelola sistem pada Kartu Prakerja. Pemasalahan lain yang sangat mungkin terjadi pada 
lapisan masyarakat adalah, tentang kompetisi liar yang terjadi antar pendaftar dimana sifat dari persaingan tersebut memang terbuka dan bebas akses tanpa melacak latarbelakang ekonomi. Sedangkan mereka tidak memikirkan tentang nasib orang-orang lain (empati) yang misalnya lebih membutuhkan, lemah ekonomi, maupun berada dalam status pengangguran?. Andaikata ketimpangan seperti itu benar-benar terjadi, maka permasalahan yang akan muncul adalah justru menghambat terciptanya pemberdayaan bahkan pembangunan. Fokus utama yang harus dibangun secara jelas, sebenarnya adalah dengan cara menyisir masyarakat-masyarakat yang tak memiliki kemampuan dan lemah secara penghasilan, sehingga lambat laun pola kehidupan mereka akan membaik. Lalu dampak yang lebih besar lagi adalah sebagai stimulasi untuk memulihkan kembali neraca perekonomian Indonesia yang goyah akibat COVID19, dengan cara aktivitas-aktivitas perekonomian yang ada pada masyarakat kecil dihidupkan kembali.

Antusiasme masyarakat yang tinggi juga turut mewarnai bertambahnya variabel masalah, sebagaimana keterangan dari Direktur Komunikasi Manajemen Pelaksana Prakerja dikutip dari (Pangastuti, 2020) yang mengungkapkan bahwa jika jumlah yang ikut (mendaftar) lebih besar dari slot (kuota) maka pihak manajemen Kartu Prakerja tidak memiliki pilihan lain untuk bagaimana caranya mendahulukan penerimaan peserta setiap pekan nya. Pada program Kartu Prakerja gelombang pertama pemerintah menyatakan bahwa penentuan kelolosan peserta adalah ditentukan oleh sistem secara acak melalui pelacakan dan verifikasi berbasiskan data (pelaku UMKM kecil, atau masyarakat terdampak COVID-19) dari Kementrian/lembaga terkait. Setiap gelombangnya kuota yang tersedia hanya lah 200.000, sedangkan jumlah peserta yang telah ter-verifikasi oleh sistem saja sudah menyentuh angka jutaan (Pangastuti, 2020).

Mengamati keterangan di atas, dapat dianalisis tentang bagaimana cara pemerintah menyiasati ketimpangan antara minimnya kuota penerimaan peserta dan membludak nya jumlah pendaftar pada tiap gelombang. Hal ini tentu saja dapat disebut sebagai hambatan pemberdayaan, karena selama penundaan berlangsung kita tidak sama-sama tahu bagaimana aktivitas masyarakat pendaftar yang belum dinyatakan lolos seleksi. Bahkan disamping itu, kemungkinan lain adalah terkait dengan nasib para pendaftar yang tentu tidak bisa untuk semuanya lolos (dikarenakan sistem tes masuk). Maka sebenarnya rancu memang jika di sisi lain pemerintah menghendaki adanya arus pemberdayaan di masa pandemi COVID-19, namun prosedur dan sistem yang telah dilaksanakan juga tidak begitu mampu mengimbangi tekanan kebutuhan dari masyarakat. Bagaimana pun, relevansi dari Kartu Prakerja hendaknya terus dilakukan peninjauan dan evaluasi supaya hambatan pemberdayaan yang terjadi di lapangan bisa melandai pada gelombang-gelombang berikutnya.

\section{PENUTUP}

Di tengah krisis akibat pandemi COVID-19, secara prinsip pemerintah Indonesia telah mengeluarkan segenap kompetensinya dalam bentuk ide dan kebijakan guna memberdayakan masyarakat terdampak. Kartu Prakerja merupakan output yang dapat dijadikan sebagai acuan, untuk merumuskan kembali tentang permasalahan fundamental yang mengendap pada kehidupan masyarakat kecil. Tidak dapat dipungkiri, antusiasme masyarakat terhadap 
kehadiran program Kartu Prakerja merupakan wujud dari himpitan ekonomi yang semakin menjadi-jadi sehingga masyarakat berusaha untuk mencari margin sekecil apapun demi mempertahankan kelangsungan hidup. Paket Kartu Prakerja bisa dibilang sebagai iming-iming nyata yang memikat perhatian seluruh lapisan masyarakat dari berbagai daerah, akan tetapi pengecualian terhadap para pejabat, ASN, serta pejabat-pejabat terkait lainnya yang memiliki ikatan kedinasan.

Kehadiran Kartu Prakerja tidak serta merta bisa dimaknai secara penuh dengan nuansa positif, ketika memang masih banyak celah kekurangan yang didapati. Secara tidak langsung, sistem Kartu Prakerja memang dijalankan secara acak (mengadu nasib) bagi para pendaftar nya yang antusias. Selain itu, bentuk seleksi yang dilakukan juga semakin menambah sempitnya kesempatan bagi masyarakat kecil. Mereka harus bersaing satu sama lain tanpa terlalu peduli dengan status sosial ekonomi, karena memang tidak diwajibkan untuk tahu. Menurut peneliti, sangat disayangkan apabila kuota dari Kartu Prakerja pada setiap gelombangnya tidak diisi oleh orang-orang yang tepat. Maksud dari orang-orang tepat disini adalah masyarakat yang tidak berdaya sama sekali, entah itu karena latarbelakang ekonomi, pendidikan, maupun sebagai imbas dari COVID-19. Triliunan anggaran yang digelontorkan melalui program Kartu Prakerja memang layak untuk terus diperhatikan dan dikaji ulang oleh pemerintah, agar supaya efektivitas dari realisasi program tersebut juga membawa pengaruh besar pada setiap sendi kehidupan di sektor-sektor masyarakat kecil dengan perbaikan prosedur tentunya.

\section{DAFTAR PUSTAKA}

Andreas, and Enni Savitri, (2016) Peran Pemberdayaan Ekonomi Masyarakat Pesisir Dan Modal Sosial Di Kabupaten Meranti Dan Rokan Hilir. 1, 1 (1). PUSTAKA SAHILA YOGYAKARTA, Yogyakarta. ISBN 602-69505-6-7

Anjaeni, R. (2020). Sri Mulyani ungkap tiga masalah ekonomi yang disebabkan pandemi Covid-19. https://nasional.kontan.co.id/news/sri-mulyaniungkap-tiga-masalah-ekonomi-yang-disebabkan-pandemi-covid-19?page $=2$

CNN. (2020). INFOGRAFIS: Pro Kontra Program Kartu Prakerja. https://www.cnnindonesia.com/nasional/20200506091934-35$500538 /$ infografis-pro-kontra-program-kartu-prakerja

Cone, N. N. C. (2020). Sudah 3 Kali Daftar Tapi Gagal Lolos Seleksi Kartu Prakerja, Coba Kamu Lakukan Hal Ini!

Consuello, Y. (2020). Analisis Efektifitas Kartu Pra-kerja di Tengah. Buletin Hukum Dan Keadilan, 4, 93-100.

Gusman, H. (2020). COVID-19: Lockdown di Beberapa Negara dan Pertumbuhan Kasus.

Hadiwardoyo, W. (2020). Kerugian Ekonomi Nasional Akibat Pandemi Covid-19. Baskara Journal of Business and Enterpreneurship, 2(2), 83-92. https: / / doi.org/10.24853/baskara.2.2.83-92

Kurniawansyah, Amrullah, M. S. (2020). Konsep Kebijakan Strategis Dalam Menangani Eksternalitas Ekonomi Dari COVID - 19 Pada Masyarakat Rentan di Indonesia. Indonesian Journal of Social Sciences and Humanities, 1(2), 130-139. https: / journal.publicationcenter.com/index.php/ijssh/article/view/117/57

Prakerja. (2020). Untuk Siapa Program Kartu Prakerja? 
https://www.prakerja.go.id/tentang-kami

Pratama, F. (2020). Menyikapi "New Normal" Setelah Pandemi.

http: / / puspensos.kemsos.go.id/menyikapi-new-normal-setelah-pandemi

Pratiwi, N. (2020). Efektivitas Kartu Prakerja di Tengah Pandemi Covid-19.

https://kaltim.tribunnews.com/2020/04/28/efektivitas-kartu-prakerja-ditengah-pandemi-covid-19? page $=2$

Silalahi, D. E., \& Ginting, R. R. (2020). Strategi Kebijakan Fiskal Pemerintah Indonesia Untuk Mengatur Penerimaan dan Pengeluaran Negara Dalam Menghadapi Pandemi Covid-19. Jesya (Jurnal Ekonomi \& Ekonomi Syariah), 3(2), 156-167. https://doi.org/10.36778/jesya.v3i2.193

Sumardiyani, W. R. (2020). Kepada Nadiem Makarim, Bima Arya Sampaikan 4 Poin Permasalahan Soal Pendidikan di Masa Covid-19. https://www.pikiranrakyat.com/jawa-barat/pr-01644647/kepada-nadiem-makarim-bima-aryasampaikan-4-poin-permasalahan-soal-pendidikan-di-masa-covid-19

Triyan Pangastuti. (2020). Antusiasme Tinggi, Pemerintah Pilih Acak Peserta Program Kartu Pra Kerja. https://investor.id/business / antusiasme-tinggipemerintah-pilih-acak-peserta-program-kartu-pra-kerja

Wijayanti, R. I., \& Humardhiana, A. (2020). Optimalisasi Program Kartu Prakerja Dengan Pelatihan Branding Strategy. DIMASEJATI, 2(1), 109-122. 